\title{
Tourism Curriculum in the University Sector: Does it Meet Future Requirements? Evidence from Australia
}

\author{
ZHI H. WANG and CHRIS RYAN
}

\begin{abstract}
In the contemporary competitive and globally connected marketplace, factors that guaranteed business success in the past may be of limited relevance in the future. Within the paradigms of today's business, many successful operators continually introduce new products and services to maintain their market leadership position. Whilst firms in the tourism industry seek to maintain competitive position through policy planning, strategic marketing, budgeting and R\&D, tourism education providers occupy a key position by seeking to enhance the skill levels of management and employees, both present and future. This paper reviews some Australian tourism and hospitality education programmes and course curriculum and briefly compares them with some trends in other English-speaking countries. The research explores tourism industry demand, trainees' expectations and additionally identifies gaps and opportunities for the future curriculum content. The findings may, therefore, assist tourism programme providers with a broader perspective with which to shape future tourism courses.
\end{abstract}

Keywords: global tourism; education programmes; demand; expectations; gaps; opportunities.

\section{Introduction}

This paper provides results derived from an exploratory study into issues pertaining to curriculum development in the university sector with reference to tourism courses at the under-graduate level. Given the nature of the data as described below, it is recognized that there exist limitations, but in what is a comparatively under-researched area it is intended that the paper should be perceived as a contribution to what should be a continuing debate rather than a definitive summary of a current situation. The paper first briefly discusses the growth of tourism and its implications for employment. Second, it briefly describes Australian reviews for tourism education. While many of these reviews relate to demand patterns not associated with university graduates, the demand for a skilled labour force is clear. Third, the text describes the nature of the research undertaken in this study followed by a statement of findings and then a general discussion. The text also draws upon the authors' own experiences of teaching tourism courses at universities in Australia, the United Kingdom, Canada and the United States.

\section{The Global Perspective}

Globally, tourism is expected to continue to grow. The United Nations World Tourism Organization (2004), anticipates international air travel to grow from 600 million trips in 2000 to 1,000 million in 2010 and then to 1,450 million in 2020. In
2002, the travel and tourism industry directly employed 72 million people worldwide and this figure rose to 198 million if associated service industries are included such as airline catering or laundry services (United Nations World Tourism Organization 2004). Tourism is no longer confined to the summer months and, in fact, less than $10 \%$ of jobs in tourism are seasonal (Prospects UK 2005a). Taking some English-speaking countries as an example, in the UK, tourism is an important industry employing more than 2.1 million people and accounting for 4.5 per cent of gross domestic product (VisitBritain 2005). The travel and tourism industry is also important in America, being the fourth largest export industry for that country. In 2003, the US travel industry received more than US\$ 554.5 billion from domestic and international travellers (excluding international passenger fares), which expenditure directly generated more than 7.2 million jobs with over US\$ 158 billion in payroll income for Americans, as well as US\$ 94.7 billion tax revenue for federal, state and local governments (Travel Industry Association of America (TIA) 2005).

\section{An Australian Perspective}

Tourism in Australia is the single largest service exporter, contributing more to GDP than agriculture, forestry and fishing, communication services, electricity, gas and

Zhi H. Wang is Senior Lecturer in Strategy and Entrepreneurship, Manchester Metropolitan University Business School, Aytoun Building, Aytoun Street, Manchester, Ml 3GH, United Kingdom. e-mail: Zhi.Wang@mmu.ac.uk

Chris Ryan is Professor in Department of Tourism Management, University of Waikato Management School, Private Bag 3105, Hamilton 3240, New Zealand. e-mail: caryan@waikato.ac.nz 
water, and personal services (Department of Industry, Tourism and Resources (DITR) 2003). In 2001-02, tourism directly contributed AUS\$ 31.8 billion to Australian Gross Domestic Product, which was 4.5 per cent of the total. In the same period it was estimated tourism generated 549, 000 jobs, which was 5.9 per cent of total Australian employment (Bureau of Tourism Research 2004; DITR 2003).

Since the 1960s, Australian Commonwealth and state governments have continually invested in tourism, particularly in international marketing and regional tourism development (Tourism Green Paper 2003). In 1998 the Howard Government released the First Action Agenda for Tourism, Tourism: A Ticket for the 21st Century, which provided AUS \$8 million for the period 1999 to 2003 to enhance regional and rural tourism. The Howard Government also used AUS\$ 50 million over four years to capitalize on the Sydney 2000 Games together with AUS\$ 8 million for a Regional Tourism Programme. The government also delivered an AUS\$ 45 million 'rescue package' in election commitments after the events of September 11, 2001 and the Ansett Collapse, followed by an additional AUS\$ 12 million for a post-SARS recovery campaign. Further, the government provided an additional funding package of AUS\$ 235 million over four and a half years to boost Australian tourism (Tourism White Paper Factsheets 2007).

Tourism Training Australia expected that between 2000 and 2005, employment in designated tourism occupations would continue to grow at $3.1 \%$ per annum, whilst jobs in the overall economy would grow at $1.7 \%$ per year (Australian Government 2002). Growing markets and changing demand both challenge the tourism industry and tourism educational providers. Consequently, the question can be posed: How can tourism and hospitality education programmes respond to the global tourism industry's future?

\section{Reactions to Tourism Growth}

In a competitive and globally connected marketplace, factors that guaranteed past business success may be of limited future relevance. The tourism industry, like other industries in this century, has experienced dramatic improvements in information technology, information and communications, and faced rapid changes of lifestyle, consumption patterns and customer preferences. This implies a need to create capable and talented staff who can manage business and people in this dynamic and competitive environment. According to the New South Wales Department of Education and the South Australian Tourism Training Association (Australian Government 2002), in recent times as demand has grown, the tourism educational sector struggled to keep up with this growth prior to 2004, when it then began to taper off. The sector is arguably now less prepared than in previous years for traineeship activity. Traineeship activity remains low and the sector has not been able to attract enough employees to meet demand. There is also a demand for teachers of courses leading to qualifications in the tourism sector (Australian Government 2002) at a number of educational levels: schools, vocational colleges and to a lesser extent, at universities.

When compared with other industries, it has been argued that universities were generally late in recognizing the development of tourism and the need to apply international business education concepts (Hjalager 2003). One school of thought is that this delayed entry and the fact that tourism programmes are unburdened by past experience, traditions and investment, paradoxically meant university tourism departments were ideally placed to cope with the constraints that seem to be emerging in many other spheres, especially with regard to supply, lack of recognition and unsatisfactory job prospects for graduates (Dewar et al. 2002). On the other hand, others have pointed out two problems: first, a lack of understanding of tourism as an academic study and the frustrating of the aims of such staff and, second, a comparative isolation of curriculum development; that is, a relative lack of linkage with more traditional disciplines and a separation from industry that limits the usefulness of graduates in the industry (Ladkin 2002).

A rapidly expanding tourism market drives the notion that tourism enterprises are in growing need of qualified staff. However, several demanding job areas remain under-addressed. For example, Australian tourism market segment growth shows that China has become one of the key niche markets in Australia. It has increased by 109,000 visitors to Australia in 2002 when compared with 1998. Japan is the second largest market in Australia (after New Zealand), followed by the UK. However, how many courses directly address the needs and structures of the Chinese outbound tourism industry? To take another example, the education tourism segment has become the second largest market in Australia since 2003 but remains in the shadow of holiday travellers. Yet this new market segment and the growth of educational tourism suggests that it is important that the tourism industry develops services to meet the expectations of these various social, cultural, consumption groups of visitors to Australia.

With reference to curriculum development, there has been some debate internationally over whether tourism studies should focus narrowly on business issues, or address wider socio-cultural issues (Airey and Johnson 1999). The issue of creating a core curriculum was rejected strongly by academics in the early $1990 \mathrm{~s}$ and has not been discussed in 
detail since (Mckercher 2002; Carlsen 2003), notwithstanding the efforts of UNWTO with its accreditation programme.

The tourism industry has been recognized as possessing a vulnerability inasmuch as any single exogenous factor can have a substantial impact on business levels (Wang 2004). Hence, for example, September $11^{\text {th }}$ and its repercussions impacted on the employment opportunities for a given generation of students and those graduating at that time. Thus, a further challenge to education providers is developing courses that enhance students' career opportunities, not simply in the tourism sector but also in other services and enterprises where knowledge of tourism might yet be a benefit to the travel industry (for example, in finance, local authority government and planning).

Tourism industry and training institutions need to look to the future and aspire to produce staff who can deliver a 'Platinum Plus' experience for students (Tourism White Paper 2004). The 'Platinum Plus' standards and experience suggests that Australia seeks to lead the world in providing quality and value in tourism products and experiences if it is to optimize growth from inbound tourism (Tourism White Paper 2004). The White Paper delivers a number of arguments familiar to those involved in tourism research. As a long-haul destination for most of the world, Australia cannot rely on strategies of price or convenience to grow its market. Australia will never be a cheap or easy destination for most of its markets. Therefore, the country must be attractive to visitors and ensure they become repeat visitors, by developing and delivering on a reputation for quality, value and varied enriching experiences (Tourism Green Paper 2003). Additionally, as the number of international visitors increases over the next 10 years and domestic visitors become increasingly discerning and demanding, the tourism sector will have to be appropriately skilled in order to meet and exceed the expectations of visitors from beyond the 'rock and reef'. Thus, tourism and hospitality education has become more sophisticated and specialized (Barrows and Bosselman 1999; Olsen and Roper 1998; Okemus 2002; Okemus and Wong 2005). It has been further recognised that $R \& D$ innovation is critical in the arena of tourism education, both as a subject to be studied and a means to be used. Innovation and technological dynamism are some of the key elements in achieving the necessary competitive edge (Archibugi et al. 1999; Bitner et al. 2000).

In order to contribute to discussion in this area, this study examined the following questions:

1. How have tourism educational programmes been developing and what is the current tourism course curriculum?
2. How have tourism educational programmes manifested both local and international features of the tourism industry?

3. What are the expectations of the students?

4. What are the industry demands of graduate skills and competencies?

5. What are the major gaps and opportunities of tourism education with reference to the global competitive future of the tourism industry?

\section{Research Methods}

To answer the above questions the resultant study had four components. It was postulated that current curriculum emerged from a historical context and perceptions of present and future needs on the part of teaching staff, industry and government (see Figure 1). Therefore, the study required data from these three stakeholders. The views of industry and government are found in various reviews cited below, but personal comments from a sample of professorial staff were elicited to provide an insight as to the first group of stakeholders. Finally, a survey of students was undertaken. Therefore, the research first undertook a review of generally representative educational programmes and programme curriculum, primarily derived from Australian universities but with some comparative data from the UK and USA as possessing some comparability as English-language speaking countries and cross fertilization of ideas through published work. Second, the first researcher directly contacted a sample of industry staff and used online data collection and document review. Third, a questionnaire was completed by a convenience sample of students at universities in New South Wales and Victoria. These states contain some of the major tourism courses in the university sector in Australia and the sample comprised students studying on such courses. The survey was carried out in 2003, and continued in 2004 and 2005. The survey was administered by the first author in each of the years with the support of staff from the institutions involved. In each year the same courses were targeted for questionnaire completion. There were a total of 240 responses, representing a response rate of $70 \%$ of the targeted population. The questionnaire included both open- and closed-ended questions. For the closed items seven-point Likert scale were used for measuring the importance of different actual or potential attributes of a tourism programme, where '7' represented the most positive part of the scale. Items were selected on the basis of past personal experience, the review of curriculum content, the comments of colleagues who saw the questionnaire and the reports cited above. 


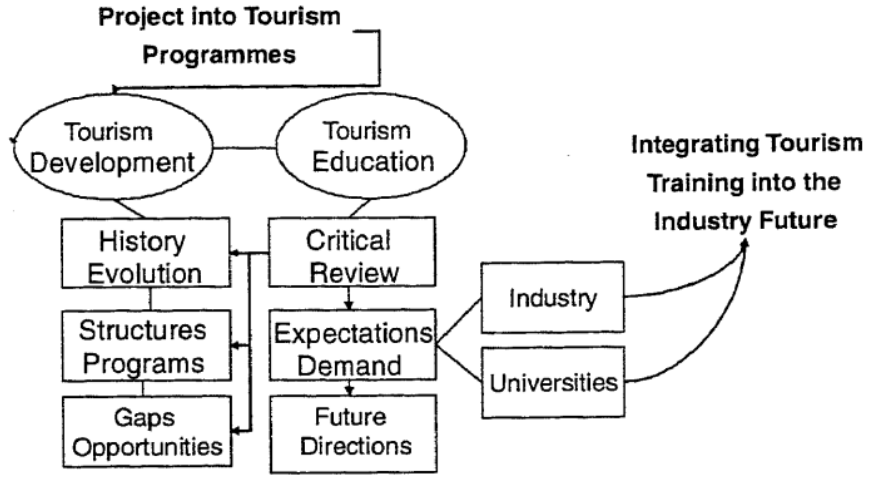

Figure 1. Project into Tourism Training and Education

Finally, the research included interviews with tourism educational staff, which sought the opinions of educational providers. Ten professors in tourism personally known to the first researcher were approached and their opinions sought on the following:

- How did tourism university education evolve in Australia?

- What are the major gaps in the current tourism education programmes at Australian universities in respect to Australian tourism industry demand in general?

- What are the major gaps in the current tourism education programmes at Australian universities with reference to the global competitive future of the tourism industry?

\section{Results}

\section{The Evolution of Curriculum}

First, a brief history of university education in tourism is described. Australian tourism and hospitality education is thought to have started in the mid-1970s at the Footscray Institute of Technology in Melbourne (part of today's Victoria University) and the Gatton Agricultural College (part of the University of Queensland) and prospered at the end of the 1980s (Carlsen 2003). There were only 4 or 5 hospitality and tourism programmes by the mid- 1980s in Australia but in the mid- 1980s the hosting of a number of significant international events (including the America's Cup in Fremantle and the World Expo in Brisbane) meant governments, industry and universities began to establish tourism and hospitality programmes in anticipation of the future growth in international tourism. By 1989, some 15 undergraduate programmes were offered.

In the 1990s, tourism education emerged as a significant force in Australian universities. James Cook University established the first full tourism department in Australia and by the end of the decade 21 out of 34 institutions offered both tourism and hospitality courses (Barrows and Bosselman 1999; Pearce 2002). By 1993, there were 22 universities offering 26 degrees in tourism and hospitality (Carlsen. 2003). By the end of 1990s, about two-thirds of all Australian universities offered tourism and/or hospitality degrees and in the early years of the 21 st century there were 29 universities offering 55 programmes in tourism in Australia. The tourism programmes show changes in the mix of tourism and hospitality programmes from parity in 1989 (10 tourism and 8 hospitality programmes) to a predominance of tourism programmes (18 tourism and 9 hospitality) in 1995.

Table 1. Tourism Education Programme Development

\begin{tabular}{|l|c|c|l|}
\hline Periods & $\begin{array}{c}\text { Number of } \\
\text { Programme }\end{array}$ & $\begin{array}{c}\text { Number of } \\
\text { Universities }\end{array}$ & $\begin{array}{c}\text { Geographical } \\
\text { Area }\end{array}$ \\
\hline Mid or late 1970s & $1-2$ & $1-2$ & Vic \\
\hline Middle of the 1980s & $4-5$ & $3-4$ & Vic, Qld \\
\hline End of the 1980s & 15 & Several & Vic, Qld, NSW \\
\hline Middle of the 1990s & 26 & 22 & Most states \\
\hline End of the 1990s & 35 & 27 & Nation wide \\
\hline In the 2000s & 37 & 28 & Nation wide \\
\hline
\end{tabular}

Sources: Australian Education (2005); Carlsen 2003; Barrows and Bosselman 1999; Pearce 2002; Sofield and Lee 1998; McKercher 2000; Wells 1996.

Table 2 summarizes the universities in 2004 that provide tourism education, classified as major to minor providers. The major providers are Southern Cross University in NSW, Victoria University in Victoria and Griffith University in Queensland. In general, NSW has a larger number of universities offering tourism courses, compared with other states and territories.

Table 2. Australian University Tourism Education Providers (2004)

\begin{tabular}{|l|l|l|l|l|}
\hline State & NSW & Victoria & Queensland & Other \\
\hline Major & SCU & VU & Griffith & \\
\hline $\begin{array}{l}\text { Near } \\
\text { maior }\end{array}$ & UTS & $\begin{array}{l}\text { La Trobe, } \\
\text { RMIT }\end{array}$ & James Cook & \\
\hline Mid size & UWS & Monash & UQ & UC, ECU \\
\hline $\begin{array}{l}\text { Near } \\
\text { minor }\end{array}$ & $\begin{array}{l}\text { CSU, } \\
\text { UNSW } \\
\text { Macawair }\end{array}$ & & CQU & US, UW \\
\hline Minor & $\begin{array}{l}\text { Usyd } \\
\text { Newcastle }\end{array}$ & $\begin{array}{llll}\text { Ballarat } \\
\text { Swinburne }\end{array}$ & $\begin{array}{l}\text { QUT } \\
\text { Sunshine } \\
\text { Coast }\end{array}$ & $\begin{array}{l}\text { Curtin, NTU } \\
\text { Murdoch, } \\
\text { Flinders, }\end{array}$ \\
\hline
\end{tabular}

Source: Australian Education (2005). 


\section{The Content of Tourism Course Curriculum}

The major provider in NSW offers nine courses/ programmes of tourism and hospitality degrees through a total 31 available subjects, including Tourism, Hotel and Resort Management, Club and Gaming, Sport, Indigenous, and Environmental Management. The major provider in Victoria also has a total of nine programmes of undergraduate courses of Tourism and Hospitality degrees. They combine Hospitality /Tourism Management with Human Resources/ Bachelor of Arts - Asian Studies/ Recreation/Bachelor of Business/Information Systems/Bachelor of Business Marketing. The major provider in Queensland has about 15 programmes of Tourism/Hospitality and related courses for the undergraduate degrees, including Bachelor of Exercise Science / Leisure, Management, Bachelor of Marketing Restaurant and Catering, Bachelor of International Business. Taken together, these providers demonstrate a range of disciplinary perspectives in tourism education in Australia. It can be argued that tourism programmes in New South Wales (NSW) mainly demonstrate its characteristics of tourism in resorts, beaches and urban areas. Comparatively, tourism courses in Victoria are more marketing-led,

Table 3. Australian Major University Tourism Courses and Programmes (2004)

\begin{tabular}{|c|c|c|c|}
\hline Regio & Course Areas & \begin{tabular}{|l} 
Course \\
Availability
\end{tabular} & \begin{tabular}{|l|} 
Total No. \\
Programmes
\end{tabular} \\
\hline NSW & $\begin{array}{l}\text { Tourism, Hotel \& Resort, } \\
\text { Club \& Gaming, Sport, } \\
\text { Indigenous, } \\
\text { Environmental } \\
\text { Management, } \\
\text { Business in } \\
\text { Tourism/Hospitality } \\
\text { Management }\end{array}$ & $\begin{array}{l}\text { Undergraduate } \\
\text { Master/MBA } \\
\text { PhD }\end{array}$ & $\begin{array}{l}9 \text { (more than } \\
31 \\
\text { subjects } \\
\text { available) }\end{array}$ \\
\hline VIC & $\begin{array}{l}\text { Tourism and Hospitality } \\
\text { Hospitality/Tourism, } \\
\text { Management with Human } \\
\text { Resource, } \\
\text { Asian Studies/ Recreation, } \\
\text { Business /Information } \\
\text { Systems, } \\
\text { Business Marketing }\end{array}$ & $\begin{array}{l}\text { Undergraduate } \\
\text { Master/MBA } \\
\mathrm{PhD}\end{array}$ & $\begin{array}{l}9 \\
\text { undergraduate } \\
\text { courses }\end{array}$ \\
\hline QLD & $\begin{array}{l}\text { Tourism/Hospitality, } \\
\text { Exercise Science, } \\
\text { Leisure Management, } \\
\text { Marketing, Restaurant and } \\
\text { Catering, International } \\
\text { Business }\end{array}$ & $\begin{array}{l}\text { Undergraduate } \\
\text { Master/MBA } \\
\mathrm{PhD}\end{array}$ & $\begin{array}{l}15 \\
\text { undergraduate } \\
\text { courses }\end{array}$ \\
\hline
\end{tabular}

Sources:

http://www.business.vu.edu.au/Schools/HTM http://www.edu.au/schools/tourism/index.php?page id=12\&me $\underline{\mathrm{nu}=3 \text { 18; }}$; Australian Education (2005). addressing the demand of urban tourism industries. Tourism programmes offered by the major provider in Queensland are more dynamic, ranging through leisure and sport science, and hospitality to international business.

From a general perspective, tourism programmes in Australia include economics; marketing; transport; planning; law; history; sports and recreation; environmental studies; socio-cultural studies; and information technology. However, the range of tourism programmes in other universities varies significantly. The orientation of most tourism and hospitality programmes is from wider arts, social-sciences, leisure or environmental studies to a general business degree though some may not show a consolidated business degree. The actual proportion of tourism content also varies significantly from a minimum 1 course ( 6 subjects) to a maximum of 15 courses (more than 37 subjects).

How does this compare with reference to other English-speaking countries? Rappole (2000) notes that there were about 149 programmes in US universities granting baccalaureate degrees, and 46 programmes granting master degrees, plus 13 others programmes offering doctoral degrees in 1998. A review of course content finds many industry-specific curricula. For example, specific papers can be found with reference to the gaming industry, the convention industry, the cruise industry and other similar segments. With reference to the UK, there university syllabi tend to be more international and strategy focused than their USA counterparts. There are a larger number of subjects including international tourism, destination analysis and strategies; strategic issues in international hospitality; strategic marketing; business strategy; international hospitality management, business ethics, entrepreneurial business development, franchising, employment law, industrial relations, issues in human resource management, organizational change and market research (http://www.som.surrey.ac.uk/student/undergraduate/programme s/modulematrix.asp). While it is difficult to generalize, it is tentatively suggested that generally tourism programmes in the UK and the North America are arguably more multidimensional than their average Australian counterparts. While all seek to provide students with a theoretical and practical understanding of tourism and related activities in the sport, event, and hospitality industries, UK and USA universities included components not normally taught in Australia such as specific industry sectors as noted above - but it should be carefully noted that infra-country differences are almost as great as inter-country differences, and arguably reflect size of institution as much as differences in philosophies. 


\section{Industry Demand}

As noted above, the research project also investigated employers' demands in terms of job skills. According to Tourism Training Australia and state tourism training agencies, the main skill shortages in urban areas are primarily in managing, marketing and several specialist areas. In more rural zones the main shortages are in customer service skills along with demonstrating the 'service culture'. Given the increasing popularity and developing demand for tourism, there is an emerging sophistication on the part of travellers and customer service demands need to be met. The demand is summarized in the Table 4 for both urban and less urban areas.

\section{Table 4. Employee and Skill Shortages Areas in Australia}

\begin{tabular}{|c|c|c|}
\hline Categories & Urban & Less Urban \\
\hline Services & $\begin{array}{l}\text { Marketing and product development } \\
\text { skills; } \\
\text { Customer service skills for front line } \\
\text { staff; } \\
\text { Management and operational skills for } \\
\text { conferences, exhibitions and events; } \\
\text { Operational skills for tour guides; } \\
\text { General skills in the provision of } \\
\text { gaming services; } \\
\text { Entrepreneurial and sales skills. }\end{array}$ & $\begin{array}{l}\text { Customer } \\
\text { service skills } \\
\text { along with } \\
\text { demonstrating } \\
\text { the 'service } \\
\text { culture' }\end{array}$ \\
\hline Managing & $\begin{array}{l}\text { Management and business skills for } \\
\text { medium to small-sized enterprises; } \\
\text { Cross-cultural and language skills; } \\
\text { Skills for managers and supervisors } \\
\text { relating to the implementation of food } \\
\text { standards and regulations; } \\
\text { Skills to formulate safety plans; } \\
\text { Operational skills for local and } \\
\text { inbound tour operators. }\end{array}$ & $\begin{array}{l}\text { Managers with } \\
\text { business, } \\
\text { leadership, and } \\
\text { human resource } \\
\text { skills at AQTF } \\
\text { levels } 5 \text { and } 6 \\
\text { are required. }\end{array}$ \\
\hline Specialist & $\begin{array}{l}\text { Commercial cookery skills; } \\
\text { Information technology skills; } \\
\text { Special interest tourism skills, such as } \\
\text { eco-tourism and adventure and } \\
\text { recreational tourism. }\end{array}$ & $\begin{array}{l}\text { Eco-tourism } \\
\text { activities, tour } \\
\text { guides with } \\
\text { interpretive } \\
\text { skills }\end{array}$ \\
\hline
\end{tabular}

Sources: Tasmanian Government (2004); Australian Government (2004); NSW Department of Education (2002).

A similar analysis of jobs-related research, was undertaken for the UK. Here it appeared that job demand in the last several years include management and marketing, recreation, sports, managing cultural and major events, tourist destination, and hospitality/ international hospitality business management (with both language and nonlanguage routes available). These jobs can be mainly categorized into the two disciplinary areas - (a) Tourism and (b) Hospitality; but in several dimensions, including managerial, services, travel, mass industry, event, and heritage. Details are displayed in Table 5.
Table 5. Multi-dimensional Job Areas in the UK

\begin{tabular}{|c|c|c|}
\hline & Management & Hospitality \\
\hline Managing. & $\begin{array}{l}\text { Management and marketing, } \\
\text { Recreation, Sports, } \\
\text { Managing Cultural and } \\
\text { Major Events Tourist } \\
\text { Destination }\end{array}$ & $\begin{array}{l}\text { Hospitality/ } \\
\text { International Hospitality } \\
\text { Business (language and } \\
\text { non-language routes } \\
\text { available) }\end{array}$ \\
\hline Serving & $\begin{array}{l}\text { Hotel manager, } \\
\text { Event organizer, } \\
\text { Public relations officer, } \\
\text { Tourism officer, }\end{array}$ & \multirow{2}{*}{$\begin{array}{l}\text { Licensed Retail, Food } \\
\text { Systems and Quality } \\
\text { Assurance Retail, Sales, } \\
\text { Hospitality Business } \\
\text { Tourist information } \\
\text { centre manager }\end{array}$} \\
\hline Travel & $\begin{array}{l}\text { Travel agency clerk/travel } \\
\text { consultant, } \\
\text { Tour Holiday representative }\end{array}$ & \\
\hline $\begin{array}{l}\text { Mass } \\
\text { Industry } \\
\text { Event, } \\
\text { Heritage }\end{array}$ & $\begin{array}{l}\text { Resort Conference, } \\
\text { Exhibition, Fundraising and } \\
\text { Sponsorship Events }\end{array}$ & $\begin{array}{l}\text { Arts administrator, } \\
\text { Historic property } \\
\text { manager, Heritage } \\
\text { officer/interpreter }\end{array}$ \\
\hline
\end{tabular}

Sources: http://www.lmu.ac.uk/lsif/the/courses.htm; Report 2005 (2005); Prospect UK (2005a)

Employers seek certain skills in addition to the specialist knowledge that graduates gain from their degree studies. Broadly speaking, the skills they referred to most frequently were in the domain of communications, teamwork and problem-solving. Interpersonal skills stand out in the area of communication. This is summarised in Table 6.

\section{Table 6. Priority of Job Skills Areas}

\begin{tabular}{|l|ll|}
\hline Priority & Job Areas & \\
\hline Higher & Communication (Oral, Written, Interpersonal) & $90 \%$ \\
& Teamwork (including Leadership skills) & $50 \%$ \\
& Problem-solving & $35 \%$ \\
\hline Medium & IT awareness for non-IT graduates & $25 \%$ \\
& Planning and Organizing (including self- & $25 \%$ \\
& management) & \\
& Initiative & $25 \%$ \\
& Flexibility, Adaptability & $25 \%$ \\
\hline \multirow{2}{*}{ Lower } & Numeracy (for non-Maths, Engineering or & $10 \%$ \\
& Science graduates) & \\
\hline
\end{tabular}

In the tourism industry where personal service to the customer is so important, an outgoing, friendly personality and the ability to think on your feet is an advantage. Good communication and presentation skills are essential and graduates need language skills to work abroad. Commercial awareness is also important, which awareness refers to a consideration of the financial impact of what is done. These skills enable employees to have a feeling for what customers need and an ability to quickly seize opportunities for new business, cutting costs or being more efficient. It is thought desirable that graduates have at least one foreign language. It is also essential that graduates can behave and present themselves in a professional manner.

Team working is crucial in order to achieve a common objective. The tourism industry will be recruiting potential 
managers and so decision-making, problem-solving, working effectively within a team and flexibility are thought essential by employers. Planning and organization were heavily emphasized. Employees should have an ability to relate well to others and to establish good working relationships.

Leadership and problem-solving skills are also emphasized by employees; namely, being able to motivate and encourage others, whilst taking the lead. Employers identified the following: a) competencies: commercial and business awareness; strategic vision and direction setting; problem-solving and decision-making; b) initiative: ability to see opportunities and to set and achieve goals; c) flexibility and adaptability: ability to handle change and adapt to new situations; d) commitment and motivation: having energy and enthusiasm in pursuing projects. Additionally, creative thinking is thought useful; that is, graduates should be inventive in their solutions to problems they encounter. An interest in the company and an enthusiasm for its work is also required, especially showing motivational achievement related to career, personal qualities, and circumstances, e.g., availability to travel.

Numeracy in terms of understanding numerical data, statistics and graphs is also considered necessary, though IT awareness and numeracy do not seem to figure strongly in the employers' documentation (Prospects UK 2005b). This is perhaps because the specialist IT and mathematical skills are assumed to be present in those graduates taking roles in computing or engineering firms.

In fact, it is interesting to see that about $60 \%$ of the vacancies advertised for graduates in the UK do not ask for specific degree subjects (Nottingham University Annual Survey of Graduates 2002). Possession of a degree is taken as evidence of intellectual ability. What is more important to the potential employer is the range of transferable skills and experience that graduates can demonstrate. Work experience and relevant post-graduate qualifications may also help make the candidates more attractive.

\section{Students' Expectations}

The survey study conducted by this research further explores the expectations of students. Feedback from the tourism students who enrolled in 2003, 2004 and 2005 at the sample of selected Australian universities is illustrated in Table 7.

The data are based on a seven-point Likert scale where seven is the highest score (the highest level of importance attributed by a respondent to an item). The perceived importance by the tourism students about the tourism programmes are calculated and ranked based on the means in 2003, 2004 and 2005. The top ranked subjects (as measured by aggregate.scores) are 'Tourism Destination Management' (means 5.3 in 2003; 5.9 in 2004, 5.6 in 2005), followed by 'Tourism Marketing'; 'Marketing Strategy in Tourism/ Hospitality'; 'Strategic Management in Tourism/Hospitality' that are equally important. These subjects had mean scores about 5 in 2003 but 6.2 in 2005, showing an increased interest of the students in these subjects. 'International Tourism

Table 7. Tourism Students' Expectations in Australian Universities (2003-2005)

\begin{tabular}{|l|r|r|r|r|}
\hline Subject areas & $\begin{array}{r}\mathbf{2 0 0 3} \\
\text { Mean }\end{array}$ & $\begin{array}{r}\mathbf{2 0 0 4} \\
\text { Mean }\end{array}$ & $\begin{array}{r}\mathbf{2 0 0 5} \\
\text { Mean }\end{array}$ & Rank \\
\hline Accounting & 3.6 & 2.9 & 4.7 & 11 \\
\hline Business Communication (Include IT) & 4.9 & 5.1 & 5.7 & 4 \\
\hline Business Law & 4 & 4.5 & 5.0 & 9 \\
\hline Buyer Behaviour & 4.3 & 3.4 & 5.4 & 10 \\
\hline Economics & 3.6 & 2.4 & 5.0 & 11 \\
\hline International Tourism Business & 5.3 & 4.9 & 5.8 & 3 \\
\hline Introductory Tourism & 5.0 & 5.6 & 5.2 & 3 \\
\hline $\begin{array}{l}\text { Marketing Strategy in } \\
\text { Tourism/Hospitality }\end{array}$ & 5.1 & 4.9 & 6.2 & 2 \\
\hline $\begin{array}{l}\text { Strategic Management in } \\
\text { Tourism/Hospitality }\end{array}$ & 5.0 & 5.1 & 6.1 & 2 \\
\hline Tourism Destination Management & 5.3 & 5.9 & 5.6 & 1 \\
\hline Tourism Employment Relations & 4.6 & 4.7 & 5.4 & 6 \\
\hline Tourism Event Management & 4.6 & 5.1 & 5.4 & 5 \\
\hline $\begin{array}{l}\text { Tourism Human Resource } \\
\text { Management }\end{array}$ & 3.6 & 5.0 & 5.6 & 8 \\
\hline $\begin{array}{l}\text { Tourism Impacts, Ethics \& } \\
\text { Sustainability }\end{array}$ & 4.4 & 5.4 & 5.4 & 4 \\
\hline Tourism Marketing & 4.7 & 5.3 & 6.2 & 2 \\
\hline Tourism Policy \& Planning & 4.3 & 5.4 & 5.5 & 4 \\
\hline Tourism Project & 3.7 & 5.4 & 5.3 & 7 \\
\hline Tourism Research Methods & 4.3 & 4.7 & 5.2 & 8 \\
\hline
\end{tabular}

Business' and 'Introductory Tourism Studies' are ranked as the fifth and sixth important subjects, in that 'International Tourism Business' mean score has increased from 5.3 in 2003 to 5.8 in 2005. The fourth rank is equally held by 'Business Communication' and Tourism Impacts followed by 'Tourism Event Management' and Tourism Employment Issues'. The lower ranked subjects are general economic and accounting subjects.

The exploration of student career development plans through the open-ended questions show that students are dynamic industry environment-oriented. They are more attracted to international companies in terms of where they choose to work. They are also marketing and management-led in terms of appointments or positions. The three highest expectations of positions by the students are 'managers' in general, followed by 'tour operators' and 'travel agents'. The students are also interested in various hospitality and event 
management, planning, and marketing posts including, ultimately, CEO positions.

The open-ended questions seeking feedback on subject preferences provided results that show a link between educational programmes and industry demand. First, more than $85 \%$ students indicate that they would like to work overseas, particularly in the UK and European countries, followed by Asia and the US. The students indicated that their choice of careers in the tourism industry was largely due to their own interests in travelling. Second, both graduates and current students see business skills as important to enable them to work in international or global firms, nominating in particular business communication, international business management, services, retailing, promotion and marketing. Most graduates felt it advantageous to have had internship training or work experience when seeking permanent employment in the industry. Another critical point is that the lecturers' knowledge in the subject domain and teaching skills are also major factors influencing the students' choices of subjects. It becomes particularly crucial if the lecturers can communicate enthusiasm to students and demonstrate a 'leading edge' component to their teaching.

\section{Expert Perspectives}

Finally, as noted above, the views of 10 tourism professors were sought. Of course, such views are personal and reflect individual institutional context, but they represent about one-third of the Australian universities, and can be treated as 'informed opinion'. It was thought that most tourism courses are atheoretical with a lack of conceptual context and links to both industry and disciplines from which the theories have been developed. Second, it was thought universities have inadequately identified industry and market demands. Consequently, this may also lead to a sudden proliferation of providers (including those from the private training sector) and hence an oversupply of potential employees. The under supply may particularly involve three areas: 1) event management, compared with greater growing trends of demand; 2) hotel management, though it has been compensated by private providers to some extent, 3) air transport and airport management, though this last may possess a modest potential for an expansion of provision in education. Other issues to emerge included a perception that current programmes have not adequately equipped students with the range of quantitative skills that they need to excel when they graduate. Indeed, some informants felt a number of programmes seem to have downgraded the depth of business skills that they provide for students, which may pose problems in the future. For example, the 'socio-political skills' required in an organization are rarely considered. It was thought necessary to take advantage of practical training to build such skills into the educational programmes. Moreover, though 'management' has been widely displayed as a prominent theme in tourism education, there are dangers that courses do not fulfil this promise, that, as one respondent commented 'like an absent host of a house party; all the guests know her name but she plays no substantial role in the event ... In tourism research and education everyone views management as a relevant theme but it is sometimes a vacuous theme, an absent host, a chimera.'

The interview results from the second question about the major educational gaps with reference to the global competitive future of the tourism industry indicate several views about weaknesses in the current tourism education programmes at Australian universities. The first 'gap' identified was that there is an imaginary construct when referring to 'the tourism industry' as a global or national unit. There is no substantial evidence for such an entity. In fact, it was argued, there are tourism industries, many of them, globally and within many countries. In terms of the competition in the international markets, the second gap is the failure by most educators to realistically deal with this diversity. The term, 'industry', is used too often to conflate two separate conditions: (a) real contested markets, and (b) markets where there is no substantial contest but a number of suppliers. Consequently, it follows there is a failure of educational programmes to address the cooperative processes at the core of every functional industry (also see Leiper 2004). Another major gap is the need to develop the connection between tourism and hospitality education and languages/cross-cultural studies. Most courses are perceived as comprising 'straight business management combinations' and few allow studies in Chinese, Japanese, Spanish or other key tourism languages, although Australian universities have been very successful at attracting students from overseas in tourism and hospitality. The establishment of THE-ICE (Tourism and Hospitality Education International Centre for Excellence) will begin, it was contended, to correct this omission. Certainly, currently few students take language options. There is also a need for subjects that enhance student understanding of cultural differences between countries and societies. Finally, a view was expressed that current tourism educational programmes lack coverage of sustainable tourism, community-based facilitators, outdoor, nature tourism, guiding and leadership areas for the international market and it was argued that, particularly in the international market, better trained and educated outdoor tourism professionals are needed. 


\section{Discussion}

Incomplete as it is, the research suggests that tourism educational programmes have passed through several stages. Hospitality and tourism education in Australia is pursued under various course titles and possess interconnected and internationalized curricula that combine general/professional and theoretical/practical components and find a balance within. However, several gaps appear to exist, including the following:

\section{A need to address the characteristics of the competitive and global industry}

For the tourism industry to compete successfully on the world stage, it must position itself strategically to meet the challenges of the dynamic industry and global competitive environment. Tourism education should demonstrate international business characteristics, and it is important to equip tourism students with business strategy skills, skills in managing international business, skills in managing human resources in multi-cultural working environments and skills in communication with multicultural clients plus IT and networking in a cross cultural context.

The international business component of studies may integrate various contemporary service industry business knowledge and strategies to develop student skills for strategic thinking, practical understanding, problem diagnosing, strategy formulation and skills of translating them into strategic practice. Such a course may be offered in the third year, drawing upon students' interdisciplinary knowledge of economics, international business, accounting, HR management and marketing, to facilitate further students' understanding of business in this competitive and global environment. The study can also be designed through selected cases in tourism and services industries in European, North American and Asia Pacific settings.

The driving forces of globalization have impacted upon human resource management in a variety of ways. Also, as company mergers and strategic alliances have become the medium for internationalization, so this has demanded a response on behalf of human resource managers to deal with employment-related consequences. The tourism industry foresees a demand for managers and employees to possess knowledge of international HR and customers. Intercultural communication is also an important issue for those working in and connected with the hospitality industry. It analyses the concepts of culture, intercultural communication, culture general and culture-specific skills, attributes of intercultural competency and perspective transformative training and education. On the 'demand-side' the emergence of the 'new tourist' also has implications for educational demand.
Intercultural communication is an important component of the tourism and hospitality industry. Therefore, it is somewhat surprising that research and teaching in intercultural communication for the tourism and hospitality industry is relatively neglected despite the increasing internationalization of the industry, the effects of globalization and the growth in international travel. The new language needs and the different cultures that tourism activities represent suggests an importance for training in these areas. Many Australians posses linguistic and cultural skills that should be utilized for economic benefit and enriching the visitor experience. The penetration of technology and particularly use of the Internet in tourism on the supply-side has demanded different skills and competencies on behalf of tourism industry employees. This too is expected to impact upon education and training programmes.

\section{Service quality and market-led Orientation}

Tourism is a people-oriented sector and friendly, efficient, professional services are a major ingredient of a skilled workforce. Being capable of sustaining high levels of services is critical for this labour-intensive industry. The tourism industry is also as vulnerable as any other to external shocks, which in the past have rocked businesses, have eroded their viability. The international business climate will continue to influence the viability of 'Tourism Australia'. Tourist business managers need to carefully monitor external factors and trends in tourism consumer choice to ensure their businesses are well positioned to weather threats to viability. Education needs to train tourism graduates to be aware of social and economic trends and the competitiveness of other leisure products and seasons. All of these play a part in consumer choice.

In an increasingly global tourism market, it is essential for the tourism industry to continually strive for improvement in its performance in order to maintain and increase its international competitiveness. One way of raising industry standards is through accreditation, that is, by developing a quality mark or brand that can be displayed by businesses which meet the required standards. Tourism is market-led and understanding the characteristics, needs, motivations, behaviour and opinions of tourists is not only of great academic interest, but is also a prerequisite to success in the industry. Sound knowledge of the market is also the key to product development as many tourism scholars and tourism managers have come to recognize. Various marketing courses can be further developed such as image making, product marketing (wine, special interest, food, attractions, culture etc), $\mathrm{PR} /$ media, trade show/consumer shows, dealing with 
the trade, generic marketing, cooperative marketing, etc. Market research is also essential. It includes network building or relationship marketing (organization to organization, individuals to individuals, individuals to organization etc).

\section{Planning Perspective}

Planning and policy should be reformed by adding in new theoretical and more practical components. The rapidly changing local and global environment shapes and influences tourism development and planning. Tourism planning should integrate into existing economic, social, and natural environments to plan strategically and address the critical issues concerned in various environments, people and places. Tourism planning, therefore, requires that future tourism policy-makers and managers possess the knowledge, techniques and skills that can ensure the success of tourism planning for a competitive and sustainable future. Planners will be required to maintain social and natural environments to enable tourism to prosper while developing strategic plans that gain support from public and private bodies. Negotiation skills will be necessary to succeed. Curriculum planning should involve the participation of industries, be appropriate for researchers and students and be reviewed frequently to be consistent with social changes and trends of the time. The centrality of the planning should be society's needs with which curricula have to accord; even while recognizing that those needs are negotiated between varying stakeholders such as business, government, communities and the needs of the natural environment.

The research reported above identified some gaps in university tourism education and suggests the need for an improvement by focusing on mainly four areas (as indicated in Figure 2). First, tourism courses need to address the dynamic characteristics of the global tourism industry.

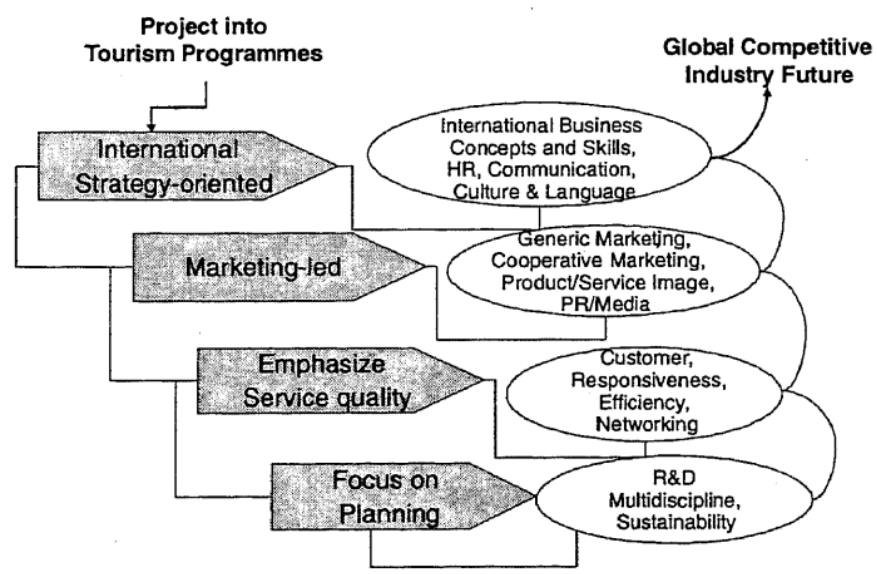

Figure 2. Summary of the Future Perspective
Second, the programmes should be marketing aware and strengthened for service quality. Third, courses can continually enable students to practice strategic planning. Tourism education development curriculum design is an extremely complex task. Differences in philosophy have important ramifications for curricula, courses structure, or instructional philosophies. Educators' background, knowledge and school traditions and developmental key points can either enhance or limit the scope of curriculum design. In general, the United States, UK and Australia share several common trends, including outreach to the international community, internationalization, international alliances, multi-cultural values and quality control. The fourth requirement is thus a need for continuous review.

It is clear that the nature of employment in tourism is changing. The response to globalisation varies across the tourism sector from transnational companies where international personnel are demanded, to the small enterprise where the impact of globalization is demanding an international standardized product and services. From a university perspective, one priority is to develop networks with industry, government and communities and create collaborative linkages across disciplinary and geographic boundaries to progress future tourism education.

\section{Conclusions}

For many involved in tourism education, there will be a sense of déjà $v u$ in much of the above. Yet while it might be objected that the above review states little that is comparatively new, that in itself represents a research finding. For all of the fact that tourism degrees have been presented in Australia for over two decades, the debate has continued in much the same way for much of that period. Why should this be? It is suggested that those who argue for curriculum change need to recognize important constraints. First, the argument tends to be about additions and extensions to existing curricula - and thus the limitations of available time in course structures need to be recognized. Second, it must be recognized that much learning takes place outside of the classroom. In an era when many students seek employment during their periods of study, and many do work within the tourism and hospitality industry, such experiences inform their learning, just as their academic Learning helps them evaluate their practical experiences. Third, much of the industry remains the province of SMEs and hence career paths, as traditionally described in other more conventional industries, are not possible - yet in that the industry is more representative of the wider economy. Thus a fourth conclusion is that over time there is a skill enhancement of the labour force as graduates slowly become more common in that labour force. 
The research is limited by size of sample, but a congruence of views emerged from the different sources documentary, opinion and from student returns - and the findings seemed to possess a contextual truth for the authors.
Each reader can come to their own opinion; and thus in that way it is hoped that this paper can sustain a necessary discussion within the field of tourism education.

\section{References}

AIREY, D. and JOHNSON, S. (1999). The Content of Tourism Degree Courses in the UK. Tourism Management 20(2): $229-235$.

ARCHIBUGI, D., HOWELLS, J. and MICHIE, J. (1999). Innovation Systems in a Global Economy. Technology Analysis and Strategic Management 11(4): 527.

AUSTRALIAN EDUCATION (2005).

http://dir.yahoo.com/Regional/Coun.tries/Australia/Education/Higher_Education/Colleges_and_Universities - Accessed on 14 February 2005.

AUSTRALIAN GOVERNMENT (2002). Research Report Number 4: Tourism workforce and Training, Australian Government, Tourism Division Department of Industry, Tourism and Resources February 2002 http://www.industry.gov.au/assets/documents/ Trinternet/4.ResearchReportNo4TourisWorkforce and Training 20050202121253.pdf - Accessed on 14 February 2005.

AUSTRALIAN GOVERNMENT (2004). Tourism Directions 2003-2004. Australia. Australian Government Department of Industry Tourism and Resources, Tourism Division.

BARROWS, C and BOSSELMAN, R. H. (1999). Hospitality Management Education. New York. Haworth.

BITNER, M. J., BROWN, S. W. and MEUTER, M. L. (2000). Technology Infusion in Service Encounters. Journal of the Academy of Marketing Science 28(1): 138-49.

BUREAU OF TOURISM RESEARCH (2004). Tourism Snapshot- domestic. Bureau of Tourism Research www.btr.gov.au - Accessed on 3 March 2005. CARLSEN, J. (2003). Australian University Tourism Education and Research. In Bridging Uncertainty, the Proceedings of $9^{\text {th }}$ Asia Pacific Tourism Association Conference. Sydney, Australia.

DEWAR, K. SAYERS, J. and MEYER, D. (2002). Hopes, Dreams and Reality: An Investigation into the Expectations and Experiences of the Tourism Graduates. Journal of Teaching in Travel and Tourism 2(1): 1-18.

DEPARTMENT Of INDUSTRY, TOURISM AND RESOURCES (DITR) (2003). DITR Annual Report for 2002-03, the• Department of Industry, Tourism and Resources. http://wwwl.industry.gov.au/department/annualreport03_04/index - Accessed on 5 March 2005.

HJALAGER, A. (2003). Global Tourism Careers? Opportunities and Dilemmas Facing Higher Education in Tourism. Journal of Hospitality, Leisure, Sport and Tourism Education 2(2): 26-37.

LADKIN, A. (2002). Career Analysis: A Case Study of Hotel General Managers in Australia. Tourism Management 23(4): 379-388.

LEIPER, N. (2004). Tourism Management (Third edition). Sydney. Pearson Education.

MCKERCHER, B. (2000). The Future of Tourism Education in Australia. In Peak Performance in Tourism and Hospitality Research (the collection of CAUTHE 2000 Refereed Research Papers). Victoria. La Trobe University.

MCKERCHER, B. (2002). The Future of Tourism Education: An Australian Scenario? Tourism and Hospitality Research 3(3): $199-211$.

NELSON, A.A. and DOPSON, L. (2001). Future of Hotel Education: Required Skills and Knowledge for Graduate of US Hospitality Programmes Beyond the Year 2000-part one. Journal of Hospitality and Tourism Education 13(5): 58-66.

NSW DEPARTMENT OF EDUCATION (2002). Strategic Plan for Vocational Education and Training 1998-2000. Australia. NSW Department of Education.

OKEMUS, F. (2002). Can Hospitality Researchers Contribute to the Strategic Management Literature. International Journal of Hospitality Management 21(2): 105-110.

OKEMUS, F. and WONG, K. F. (2005). In Pursuit of Contemporary Content for Courses on Strategic Management in Tourism and Hospitality

Schools. International Journal of Hospitality Management 24(2): 259-279.

OLSEN, M. and ROPER, A. (1998). Research in Strategic Management in the Hospitality Industry. International Journal of Hospitality Management 17 $\therefore 111-124$

PEARCE, P. L. (2002). The Curriculum Reform and Trends in Hospitality Education in Australia. In H. J. Shyan (Chair) The Curriculum Reform and Trends of Hospitality Education Development. Proceedings of 2002 Hospitality Education International Conference. Taipei. Taiwan: 119-141. PROSPECTS UK (2005a). http://www.prospects.ac.uk/downloads/signpostsheets/ Degree_in_travel_and_tourism.pdf - Accessed on 22 March 2005. PROSPECTS UK (2005b). What do employers look for? http://www.prospects.ac.uk/cms/ShowPage/homepage/Applications_and_interviews/Applications/

What_do_employers look for/pleebcp - Accessed on 22 March 2005.

RAPPOLE, L. C. (2000). Update of the Chronological Development, Enrolment Patterns, and Education Models of four-Year, Master's and Doctoral Hospitality Programmes in the United State. Journal of Hospitality and Tourism Education 12(3): 24-27.

REPORT 2005 (2005). Employers' Needs and Graduate Skills, http://www.surrey. ac.uk/Skills/reports/graduate/appendixa.html - Accessed on 22 March 2005.

SOFIELD, T. and LEE, D. (1998). Studies of the International Tourism Education - Australia. China. Dong-A University.

TASMANIA GOVERNMENT (2004). Tourism Training Tasmania Industry Vocational Education Plan 2001-2003 http://www.voced.edu.au/cgibin/get-iso8.pl?off=30577492\&db=voced\&patlist=keywords\%3Aworkers\%20participation - Accessed on 14 April 2004. 
Tourism Curriculum in the University Sector: Z. H. Wang and C. Ryan

TRAVEL INDUSTRY ASSOCIATION OF AMERICA (TIA) (2005). Travel Industry Association of America, http://www.tia.org/Travel/ default.asp Accessed on 23 March 2005.

TOURISM GREEN PAPER (2003). A Medium to Long Term Strategy for Tourism Green Paper. Tourism Industry Resources. Competitive Australia (last updated 29-Oct-2003) http://www.industry.gov.au/search/search.cfm - Accessed on 14 September 2003.

TOURISM WHITE PAPER (2004). A Medium to Long Term Strategy for Tourism Australian Government Tourism White Paper (Last updated 07Jan-2004) http://www.industry.gov.au/search/search.cfm - Accessed on 14 April 2004.

TOURISM WHITE PAPER FACTSHEETS (2007). http://www.nml.csiro.au/content/itrinternet/cmscontent.cfm?objectID=AEDC44AA-65BF4956-B977456915EB4D78 - Accessed on 8 March 2007

VISITBRITAIN (2005). http://www.visitbritain.com/presscentre, 2005 - Accessed on 8 March 2005.

WANG, Z. (2004). Impact of Sep $11^{\circ}$ and Challenge to Business Approaches 2004. Paper Presented in Global. Business and Finance Research Conference, London July 14-17. 2004.

WELLS, J. (1996). The Tourism Curriculum in Higher Education in Australia 1989 - 1995. Journal of Tourism Studies 7(1): $20-30$.

UNITED NATIONS WORLD TOURISM ORGANISATION (UNWTO) (2004). WTO 2020 Vision: Forecast of Inbound Tourism, World by Regions WTO data base 2004. www.tctas.com.au/documents/SummaryTourismandHospitalityTraining Demand.pdf - Accessed on 8 March 2006.

\section{Websites Visited}

http://www.lmu.ac.uk/lsif/the/courses.htm - Accessed on 12 February 2004.

http://www.business.vu.edu.au/Schools/HTM/ - Accessed on 12 February 2004.

http://www.edu.au/schools/tourism/index.php?page_id=12\&menu=3_18 - Accessed on 12 February 2004.

http://www.griffith.edu.au/acadernicprogrammesandcourses/ - Accessed 12 February 2004.

http://www.som.surrey.ac.uk/student/undergraduate/programmes/modulematrix.asp - Accessed 12 February 2004. 